\title{
THE FOOD ACQUISITION PROGRAM AS AN INDUCER OF FOOD SOVEREIGNTY
}

\author{
https://doi.org/10.4215/rm2019.e18024
}

Maurício Ferreira Mendes a* - Sandra Mara Alves da Silva Neves b - Tamires da Silva Machado ${ }^{c}$

(a) Dr. in Geography. Professor Federal University of Tocantins, Araguaína (TO), Brazil.

ORCID: https://orcid.org/0000-0003-4801-0227. LATTES: http://lattes.cnpq.br/1544463117481487.

(b) Dr. in Geography. Professor State University of Mato Grosso, Cáceres (TO), Brazil.

ORCID: https://orcid.org/0000-0002-2065-244X. LATTES: http://lattes.cnpq.br/6430066425008976.

(c) Msc. in Environment and Agricultural Production Systems. Professor Federal Institute of Mato Grosso, Campo Novo dos Parecis (MT), Brasil.

ORCID: https://orcid.org/0000-0002-5538-1168. LATTES: http://lattes.cnpq.br/6186601473493125.

Article history:

Received 12 July, 2019 Accepted 7 October, 2019 Publisher 15 October, 2019

\section{(*) CORRESPONDING AUTHOR}

Address: UFT, Avenida Paraguai, s/nº, CEP: 78824-838, Araguaína (TO), Brasil. Tel: (+55 63) 34165608.

E-mail: E-mail: mauricio.mendes@uft.edu.br

\begin{abstract}
The objective of this paper is to analyze the Simultaneous Donation Purchase modality of the Food Acquisition Program (PAA) in Mato Grosso state, emphasizing the diversified production, family consumption and promotion of food sovereignty among the peasants and those people served state, emphasizing the diversified production, family consumption and promotion of food sovereignty among the peasants and those people served
by the program. The four main methodological procedures used were: bibliographic and documentary research, data collection, the elaboration of cartographic representation, and the analysis of primary and secondary data. The primary data were collected from February to July 2016 , through semi-structured interviews with peasant leaders who access or have accessed the PAA and the secondary data came from the National Supply Company (Conab). The findings were that the PAA impacts on social inclusion, strengthening peasant agriculture, which produces enough good quality food to meet the families' dietary requirements and offers the possibility of selling any surplus. It is concluded that food sovereignty affirms the right of peasants and the people benefiting from the program to a culturally appropriate diet and the resources to produce food, thus reducing their dependence on capitalist markets.
\end{abstract}

Keywords: Public policy, food production, social assistance.

\section{Resumo / Resumen}

\section{O PROGRAMA DE AQUISIÇÃo DE ALIMENTOS COMO INDUTOR DA SOBERANIA ALIMENTAR}

O objetivo deste trabalho é analisar o Programa de Aquisição de Alimentos (PAA) em Mato Grosso, na modalidade Compra com Doação Simultânea, enfatizando a produção diversificada, o consumo familiar e a promoção da soberania alimentar entre os camponeses e as pessoas atendidas pelo programa. Foram adotados quatro procedimentos metodológicos principais: I) pesquisa bibliográfica e documental; II) coleta de dados; III) elaboração de representação cartográfica e; IV) análise de dados primários e secundários. Os dados primários foram coletados no período de fevereiro a julho de 2016, por meio entrevistas semiestruturadas com lideranças de camponeses que acessam ou acessaram o PAA e os secundários na Companhia Nacional de Abastecimento (Conab). Verificou-se que o PAA atua na inclusão social, fortalecendo a agricultura camponesa, que produz alimentos de qualidade e em quantidade suficiente para atender o consumo da própria família, com possibilidade de comercializar o excedente. Assim conclui-se que a soberania alimentar afirma o direito dos camponeses e pessoas atendidas pelo programa a uma alimentação culturalmente apropriada, aos recursos para produzir alimentos, reduzindo sua dependência de mercados capitalistas.

Palavras-chave: Política pública, produção de alimentos, assistência social.

\section{EL PROGRAMA DE ADQUISICIÓN DE ALIMENTOS COMO INDUCTOR DE LA SOBERANÍA ALIMENTARIA}

El objetivo de este trabajo es analizar el Programa de Adquisición de Alimentos (PAA) en Mato Grosso, en la modalidad Compra con Donación Simultánea, enfatizando la producción diversificada, el consumo familiar y la promoción de la soberanía alimentaria entre los campesinos y las personas atendidas por el programa. Se adoptaron cuatro procedimientos metodológicos principales: I) investigación bibliográfica y documental; II) recopilación de datos; III) elaboración de representación cartográfica y; IV) análisis de datos primarios y secundarios. Los datos primarios fueron recolectados en el período de febrero a julio de 2016, por medio de entrevistas semiestructuradas con líderes de campesinos que acceden o acceden al PAA y los secundarios en la Compañía Nacional de Abastecimiento (Conab). Se verificó que el PAA actúa en la inclusión social, fortaleciendo la agricultura campesina, que produce alimentos de calidad y en cantidad suficiente para atender el consumo de la propia familia, con posibilidad de comercializar el excedente. Así se concluye que la soberanía alimentaria afirma el derecho de los campesinos y personas atendidas por el programa a una alimentación culturalmente apropiada, a los recursos para producir alimentos, reduciendo su dependencia de mercados capitalistas.

Palabras-clave: Política pública, producción de alimentos, asistencia social. 


\section{INTRODUCTION}

In Brazil, public policies implemented for the peasantry, such as the Food Acquisition Program (PAA), are a relatively recent phenomenon. The first of these experiences were localized and often discontinuous over time, they mainly took place in the South of the country and were developed by municipal and state governments, interested in encouraging peasant agriculture and local food production (SCHIMITT and GUIMARÃES, 2008).

The PAA is a strategic program that articulates any surplus food generated by family units so that it can be traded through the institutional market. In countries such as France, where government procurement is a public policy priority, the peasants' participation by means of associations, cooperatives, and formal groups is an important strengthening strategy. In Brazil, peasants have always been marginalized in public food purchase programs (CONCEIÇÃO, 2015).

It is noteworthy that the PAA, established by Article 19 of Law n ${ }^{\circ} .10 .696 / 2003$ (BRAZIL, 2003), through the now extinct Ministry of Social Development and Hunger Alleviation (MDS), waives the submission of bids for government purchases of peasants' agricultural products, stimulating short commercialization circuits. In the law, the waiver is defined as follows:

(i) the products must be purchased from family farmers within the National Family Farming Program (PRONAF); (ii) these acquisitions are intended to encourage family farming, including actions linked to the distribution of these products to persons suffering from food insecurity and the formation of strategic stocks; (iii) in order for bidding to be waived, the acquisition prices must not be higher than those prevailing in the regional markets. This is an exception to the complex procurement procedures established by Law No. 8,666/1993 (Law on Procurement and Administrative Contracts), which practically prevents the access of the vast majority of small farmers to institutional markets (SCHIMITT and GUIMARÃES, 2008, p. 9).

The PAA stipulates that purchases should be based on the reference prices practiced in each of the country's regions, according to surveys carried out in markets, community vegetable gardens, and rural settlements, among others. According to Schmitt and Guimarães, "this is another innovation, as the Minimum Price Guarantee Policy, created in 1945 and restructured in the 1960s, has always used a universal mechanism, officially to serve all rural producers" (2008, p. 9).

Through Decree $N^{\circ}$. 7.775/2012 (BRAZIL, 2012), the PAA is now part of the National Food and Nutrition Security System (SISAN). Therefore, the program deals with one of the most significant social problems, which is to improve the supply of good quality, diversified food to people suffering from food insecurity, whilst simultaneously providing peasant families with job opportunities and new income appropriation, creating local markets for commerce. Conceição states that "this program is capable of transforming reality by inserting a significant portion of rural producers in the productive sphere, actually promoting rural development" (2015, p. 146).

The theme of food sovereignty has gained great political projection in Brazil in recent years because it references the actions of various social movements linked to the rural setting, such as specific public policies for the sector. Jalil asserts that "the current discussion on food sovereignty in Brazil encompasses a diversity of political approaches and social practices that are developing from the complexity of our social, political, economic and cultural reality" (2009, p. 9).

The PAA is the first government policy to support the commercialization of peasant production in the entire history of Brazil. It also contributes directly to social organization and production in settlements and rural communities, encouraging sustainable and/or agroecological production. The various products (cereals, tubers, flours, vegetables, seeds, and others) are purchased by the Federal Government through the Conab, and then sent to social entities, schools, hospitals, and vulnerable people affected by food insecurity, as well as being used to stockpile strategic goods.

The PAA is a counterpoint to several structural problems, which include low prices and the lack of appreciation of peasant production imposed by industrialization and large economic groups, laws that focus completely on large enterprises, the lack of inclusion in institutional markets, an absence of public policies and the difficulties and bureaucracy involved in releasing credit for family enterprises (PANDOLFO, 2008). The objective of this paper is to analyze the Purchase with Simultaneous Donation 
modality of the PAA in the Brazilian state of Mato Grosso, with an emphasis on diversified production, family consumption and the promotion of food sovereignty among the peasants and the people served by the program.

\section{MATERIAL AND METHODS}

\section{Study Area}

The study area is Mato Grosso state, a federative unit in Brazil. The analysis and data covered the twelve state planning regions (MATO GROSSO, 2012). Located in the Center-West region of Brazil, the state has a territorial extension of $903,329,700 \mathrm{~km} 2$, with 141 municipalities, 3,035,122 inhabitants, and a population density of 3.36 inhabitants $/ \mathrm{km} 2$ (IBGE, 2010). Its economy is based on agriculture and its natural environment is home to three biomes: Amazon, Cerrado and Pantanal. Mato Grosso' planning regions and their respective municipalities are given below (Figure 1): i. Region I - Northwest I: Aripuanã, Castanheira, Colniza, Cotriguaçu, Juína, Juruena, and Rondolândia; ii. Region II - North: Alta Floresta, Apiacás, Carlinda, Colíder, Guarantã do Norte, Matupá, Nova Bandeirantes, Nova Canaã do Norte, Nova Guarita, Nova Monte Verde, Nova Santa Helena, Novo Mundo, Paranaita, Peixoto de Azevedo, and Terra Nova do Norte; iii. Region III - Northeast: Alto Boa Vista, Bom Jesus do Araguaia, Canabrava do Norte, Confresa, Luciara, Novo Santo Antonio, Porto Alegre do Norte, Santa Cruz do Xingu, Santa Terezinha, São Felix do Araguaia, São Jose do Xingu, Serra Nova Dourada, and Vila Rica; iv. Region IV - East: Água Boa, Araguaiana, Araguainha, Barra do Garças, Campinápolis, Canarana, Cocalinho, General Carneiro, Nova Nazaré, Nova Xavantina, Novo São Joaquim, Pontal do Araguaia, Ponte Branca, Querência, Ribeirão Cascalheira, Ribeirãozinho, and Torixoréu; v. Region V - Southeast: Alto Araguaia, Alto Garças, Alto Taquari, Campo Verde, Dom Aquino, Gaucha do Norte, Guiratinga, Itiquira, Jaciara, Juscimeira, Paranatinga, Pedra Preta, Poxoréu, Primavera do Leste, Rondonópolis, Santo Antonio do Leste, São Jose do Povo, São Pedro da Cipa, and Tesouro; vi. Region VI - South: Acorizal, Barão de Melgaço, Chapada dos Guimarães, Cuiabá, Jangada, Nobres, Nossa Senhora do Livramento, Nova Brasilândia, Planalto da Serra, Poconé, Rosário Oeste, Santo Antonio de Leverger, and Várzea Grande; vii. Region VII - Southwest: Araputanga, Cáceres, Campos de Júlio, Comodoro, Conquista D'Oeste, Curvelândia, Figueirópolis D’Oeste, Glória D’Oeste, Indiavaí, Jauru, Lambari D'Oeste, Mirassol D'Oeste, Nova Lacerda, Pontes e Lacerda, Porto Esperidião, Reserva do Cabaçal, Rio Branco, Salto do Céu, São José dos Quatro Marcos, Sapezal, Vale de São Domingos, and Vila Bela da Santíssima Trindade; viii. Region VIII - West: Barra do Bugres, Brasnorte, Campo Novo do Parecis, Denise, Nova Olímpia, Porto Estrela, Santo Afonso, and Tangará da Serra; ix. Region IX - Center-West: Alto Paraguay, Arenápolis, Diamantino, Nortelândia, Nova Marilândia, Nova Maringá, and São José do Rio Claro; x. Region X - Center: Lucas do Rio Verde, Nova Mutum, Santa Rita do Trivelato, Sorriso, Tapurah, and Itanhangá; xi. Region XI - Northwest II: Juara, Novo Horizonte do Norte, Porto dos Gauchos, and Tabaporã; xii. Region XII - North Center: Cláudia, União do Sul, Itaúba, Feliz Natal, Marcelândia, Nova Ubiratã, Santa Carmem, Sinop, Vera, and Ipiranga do Norte. 


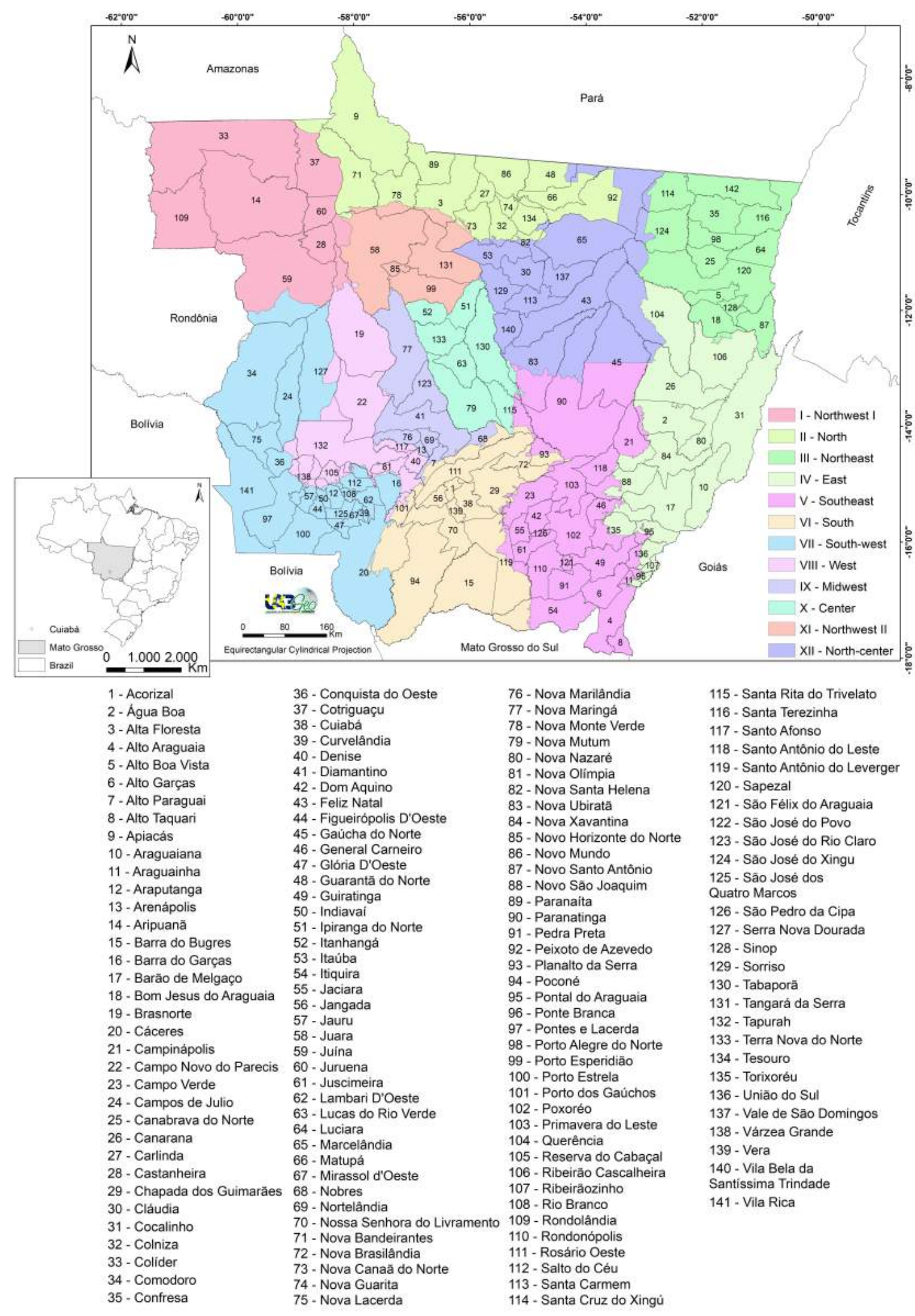

Figure 1 - Planning regions of the state of Mato Grosso, Brazil (2016). Prepared by: LabGeo/UNEMAT.

\section{METHODOLOGICAL STRATEGIES}


Four main methodological procedures were adopted for the research: bibliographic and documentary research, data collection, the elaboration of the cartographic representation, and the analysis of primary and secondary data (SAQUET et al., 2010). The Bibliographic and documentary research, as well as the secondary data analysis, were carried out in accordance with Gerhardt and Silveira (2009).

The treatment of the data collected to create the cartographic material used the ESG ArcGis Geographic Information System, version 10.4.1 to generate the Geographic Database - BDG and the subsequent maps and quantifications in this article.

The data for the study came from the National Supply Company (CONAB), through the Directorate of Agricultural Policy and Information (DIPAI), the Superintendence for Family Farming Support (SUPAF), the Family Farming Monitoring and Control Management (GECAF) in Brasília/DF and CONAB/SUREG/MT. The time frame was from 2009 to 2014.

From February to July 2016, interviews were conducted to reinforce the research and the answers were recorded on forms and through photographs. The results were divided into two categories: a) 13 (thirteen) interviews with academics in this field, who are researchers at Higher Education Institutions: UNEMAT, UFG and IFMT, from the Extension Center for Territorial Development (NEDET/UNEMAT), the Caceres School Meals Coordination, the Municipal Agriculture Secretariats of Cáceres and Mirassol D'Oeste, the National Supply Company (CONAB/SUREG/MT), the Mato Grosso Rural Research and Extension Company (EMPAER-MT), and the Cáceres and Mirassol D'Oeste's Rural Workers Unions; b) 25 (twenty-five) interviews with peasant leaders and their respective associations/cooperatives, which participated in the PAA public policy, to investigate how the project design was organized, and how the program in Mato Grosso was operationalized and put into practice.

This research was authorized on September 29, 2015, by the Research Ethics Committee of the Federal University of Goiás (CEP/UFG), Opinion n ${ }^{\circ}$ 1.249.106.

\section{RESULTS AND DISCUSSION}

Mato Grosso's peasants have been participating in the PAA since 2005, when through their Regional Association of Agroecological Producers (ARPA), based in Mirassol D'Oeste, peasants from the Southwest region began their first PAA project, acting as pioneers in the State (CONAB/SUREG/MT, 2015).

The ARPA presented a Purchase with Simultaneous Donation PAA project involving ten families, who produced and commercialized $11,184.96 \mathrm{~kg}$ of various peasant food crops, generating an income of R\$ 20,392.29 and serving 804 students in three schools in settlements in Mirassol D'Oeste and Curvelândia (CONAB/SUREG/MT, 2015).

Since its inception in 2003, the Purchase with Simultaneous Donation Food Acquisition Program (PAA-CDS) has been the most commonly accessed by peasants throughout Brazil and Mato Grosso and is the most resource-intensive modality. The PAA-CDS is operated by Conab, due to the dynamism of its operation, the guaranteed market and the added value of production. Small farmers "donate the products from the beneficiary suppliers, as defined in the Participation Proposal, to the previously selected Receiving Units (social assistance networks and food and nutrition facilities)" (CONAB, 2015, p. 2).

In 2014, 51,228 peasants attended by the PAA-CDS modality were benefited throughout Brazil (CONAB, 2016). In 2014, in the state of Mato Grosso, 1,812 peasants participated in the modality. From 2009 to 2014, 15,289 peasants, agrarian reform settlers and traditional extractivists benefited from the policy in the state (CONAB/SUREG/MT, 2015). The connection between peasants and food sovereignty is evident, since they produce most of the food for internal consumption (PIMBERT, 2009).

In 2009, peasants from 16 municipalities in Mato Grosso located in eight planning regions accessed the PAA-CDS through associations and/or cooperatives. In 2010, this number peaked at 56 municipalities in eleven planning regions. In 2011, 43 municipalities in eleven regions joined the program and in 2012 this number rose to 51 municipalities in eleven state planning regions. In 2013, 27 participating municipalities were distributed in nine regions and finally, in 2014, 32 municipalities were 
spread over eight planning regions (see Figure 2). These results are similar to the findings of Scheuer, Snows, and Mendes (2014) who identified 26 municipalities served by the PAA in the state of Mato Grosso in 2013.
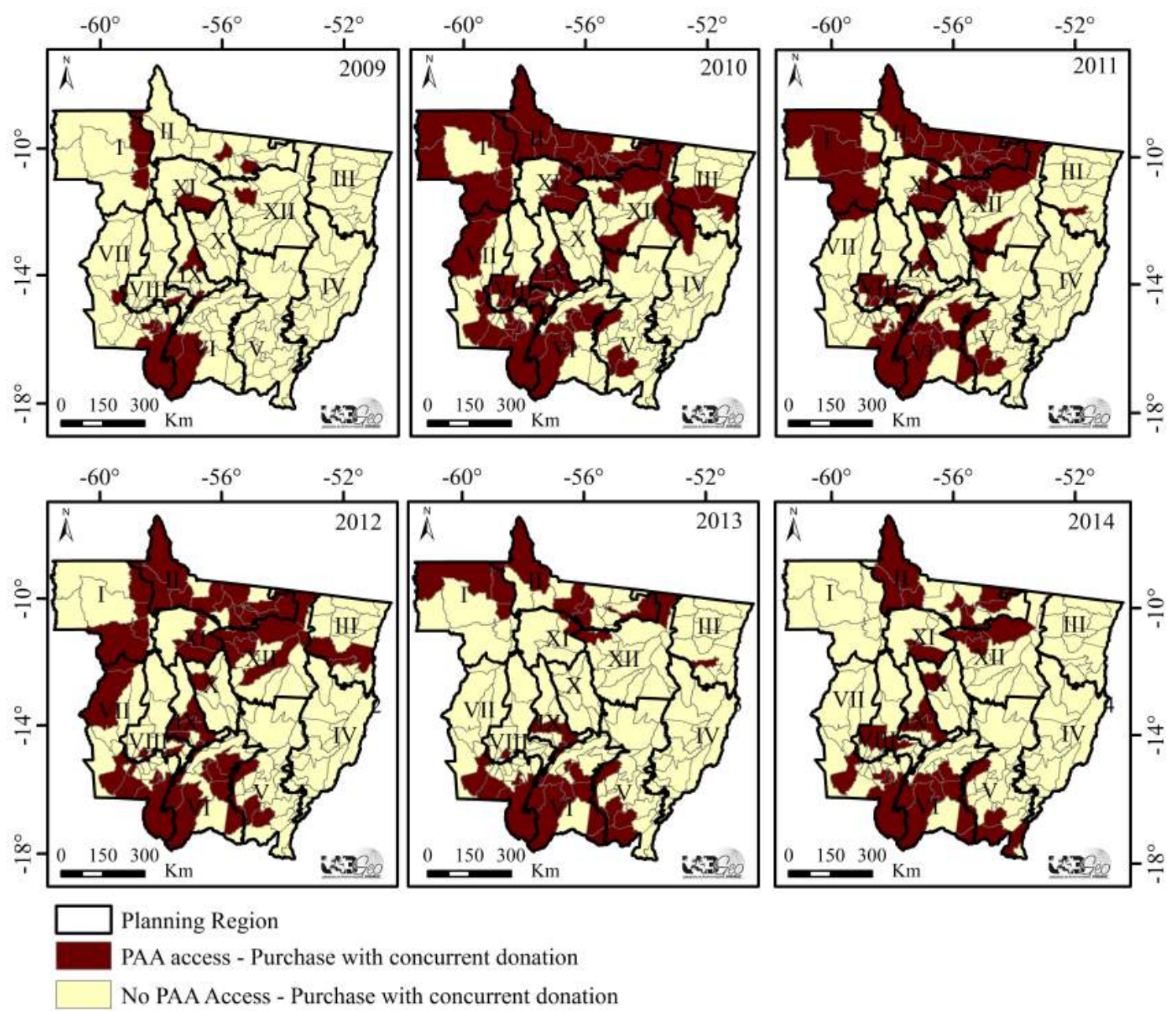

Figure 2- The distribution of access of municipalities and planning regions in Mato Grosso to the PAA-CDS, from 2009 to 2014. Prepared by: LabGeo/UNEMAT.

This study found that there were fluctuations in the increase and decrease in municipal participation from one year to another. The biggest increase in municipalities accessing the PAA-CDS was $250 \%$ from 2009 to 2010 and the largest decrease was $-89 \%$ between 2012 and 2013 . This may be related to how the PAA disseminated its work in rural communities and settlements and also to the budget available for the projects filed with CONAB/SUREG/MT. Mendes (2017) states that the PAA's continuity has been threatened in recent years as a result of the dismantling of financial resources for agrarian reform and peasant agriculture, which directly impacts the number of Conab projects implemented from one year to the next. (MENDES, 2017).

Figure 2 shows that the best performance in 2009 was in planning region VII (Southwest), with five municipalities joining the PAA: Cáceres, Conquista D'Oeste, Curvelândia, Mirassol D'Oeste and São José dos Quatro Marcos. The next was region I (Northwest I) with three municipalities, and regions II (North) and IX (Center-west), with two municipalities each. Regions VI (South), VIII (West), XI (Northwest II) and XII (Central North) each had one municipality in the program. Regions III (Northeast), IV (East), V (Southeast) and X (Center) had no municipalities participating in the PAA in the period.

Besides ranking first in 2009, the peasants of the municipalities of Cáceres, Mirassol D'Oeste and São José dos Quatro Marcos are noteworthy for their use of agroecological farming techniques, 
especially for vegetable crops (MENDES, 2017). Other field data shows that several social movements are active in the region, such as the Landless Rural Workers Movement (MST), the Small Farmers Movement (MPA), peasants' unions and NGOs.

In 2010, region II (North) had the most municipalities participating in the PAA, totaling 14 municipalities: Alta Floresta, Apiacás, Carlinda, Colíder, Matupá, Nova Bandeirantes, Nova Canaã do Norte, Nova Guarita, Nova Monte Verde, Nova Santa Helena, Novo Mundo, Paranaíta, Peixoto de Azevedo, and Terra Nova do Norte. In second place was region VII (Southwest) with 11 municipalities, followed by regions I (Northwest I) and VI (South) with six municipalities each. Regions VIII (West) and IX (Center-west) had four municipalities each, and regions V (Southeast) and XII (Central North) each had three participating municipalities. Two municipalities took part from both regions III (Northeast) and XI (Northwest II), and region IV (East) had a single municipality accessing the PAA. There were no municipalities taking part in the program in region X (Center). The rise of region II (North) is due to its inclusion in the "Portal da Amazônia" Citizenship Territory, an MDA policy whose actions include the structuring of a program with a commercialization network, based on products from peasant agriculture (OLIVAL, 2005).

In 2011, region II (North) was still the planning region with the largest number of municipalities accessing the PAA-CDS, with 13 participants: Alta Floresta, Apiacás, Carlinda, Colíder, Guarantã do Norte, Matupá, Nova Guarita, Nova Monte Verde, Nova Santa Helena, Novo Mundo, Paranaíta, Peixoto de Azevedo, and Terra Nova do Norte. Next were regions VI (South) and VII (Southwest) with five municipalities each and then regions I (Northwest I) and XII (Central North) with four municipalities each. Both regions V (Southeast) and VIII (West) had three municipalities taking part and regions IX (Center-west) and XI (Northwest II) had two municipalities, followed by regions III (Northeast) and X (Center) with one municipality each. No municipalities from region IV (East) were included in the program that year.

In 2012, region II (North) continued to be the planning region with the largest number of municipalities accessing the PAA-CDS, with a total of 12 municipalities: Alta Floresta, Apiacás, Carlinda, Colíder, Matupá, Nova Bandeirantes, Nova Guarita, Nova Monte Verde, Nova Santa Helena, Novo Mundo, Peixoto de Azevedo, and Terra Nova do Norte. Next, were region VII (Southwest) with eight municipalities and region VI (South) with six municipalities, followed by region XII (North Center) with five municipalities accessing the PAA-CDS. Both regions I (Northwest I) and IX (Center-west) had four municipalities participating and regions V (Southeast), VIII (West) and XI (Northwest II) had three municipalities each. Region III (Northeast) had two municipalities and finally, there was one municipality from region X (Center). In region IV (East) there were no municipalities accessing the modality in 2012 .

In 2013, the municipalities in planning regions II (North): Alta Floresta, Apiacás, Carlinda, Nova Canaã do Norte, and Peixoto de Azevedo; VI (South): Acorizal, Nossa Senhora do Livramento, Poconé, Santo Antonio do Leverger, Cuiabá; and VII (Southwest): Cáceres, Mirassol D'Oeste, Pontes e Lacerda, Porto Esperidião and Reserva do Cabaçal accessed the PAA-CDS the most, with five municipalities in each. Region V (Southeast) followed with four municipalities, then region I (Northwest I) with three municipalities. Region IX (Center-west) had two municipalities participating, and regions III (Northeast), VIII (West) and XII (Central North) had one municipality each. There were no municipalities accessing this PAA modality in regions IV (East), X (Center) and XI (Northwest II) in 2013. The predominance of the northern region is confirmed by Scheuer, Snows, and Mendes (2014) in PAA mapping in the state of Mato Grosso in 2013, which highlighted the use of agroecological techniques in Alta Floresta.

In 2014, ten municipalities from region II (North) took part in the PAA-CDS: Apiacás, Carlinda, Colíder, Guarantã do Norte, Matupá, Nova Bandeirantes, Nova Guarita, Nova Monte Verde, Nova Santa Helena, and Terra Nova do Norte. Next were regions VI (South) and VII (Southwest) with five municipalities each, then the V (Southeast), IX (Center-west) and XII (Central North) regions with three municipalities each. Region XI (Northwest II) had two municipalities participating and region VIII (West) had one municipality. No municipalities from Regions I (Northwest I), III (Northeast), IV (East) and $\mathrm{X}$ (Center) accessed the PAA-CDS in the period.

The results indicate that region II (North) and region VII (Southwest) are the main proponents of 
PAA-CDS projects. These data corroborate the work of Mendes (2012), who states that the government cannot reach all the state's municipalities, hence the importance of the work of NGOs and Rural Workers Unions in the dissemination of information about the program in settlements and rural communities, which can influence the amount of participation in the different regions. Another factor in Mato Grosso is the lack of public Technical Assistance and Rural Extension (ATER) for the elaboration of PAA projects, which according to the fieldwork hinders the access of many peasant farmers.

The Mato Grosso Rural Research and Extension Company (EMPAER-MT), which provides technical assistance to farmers, has been completely dismantled.

The agency [Empaer] continues without the minimum working conditions for the staff, nor can it guarantee quality technical assistance to the thousands of people still trying to survive in family farming in Mato Grosso. The neglect begins at the current Empaer headquarters. Greenhouses overgrown with weeds, rusty labs, vehicles that have not been maintained and without fuel, no funds for assistance, and shortages of inputs and professionals complete the company's gloomy situation. According to the president of the Mato Grosso State Research, Assistance and Rural Extension Workers Union (Sinterp), Gilmar Brunetto, the State Government only has eyes for agribusiness and ignores family farmers (MIRANDA, 2013, p. 1).

Even in the state planning regions, local knowledge and knowledge are undervalued. However, in the last decade, there has been ongoing discussion in region VII (Southwest) about agroecological production, the industrialization of agriculture, commercialization and organization, and the strengthening of peasant women's collectives, with investments in logistics, training and production organization. In this sense, the PAA is one of the instruments that contribute to the valorization of local knowledge, diversified production, and agroecology (ASSIS et al., 2017).

Regarding the PAA-CDS in Mato Grosso, it is also important to highlight the quantity and diversity of the products sold through this public policy modality, as a diversified diet directly contributes to the health of peasant families, in addition to forming healthier eating habits in the students and other beneficiaries (MENDES, 2012).

According to an interview with a peasant from the municipality of Vila Bela Santíssima Trindade, who sells fruit pulp such as tamarind, araçá-boi (Eugenia stipitate), and cupuaçu (Theobroma grandiflorum), through the PAA-CDS in local schools in the urban and rural area "first it is necessary to promote a sufficient, healthy diet for their own family and then trade the surplus, the PAA helps many people with commercialization" (MP, 2015).

The quantity and diversification of food from peasant agriculture marketed through the PAA-CDS is quite significant, ranging from projects like the Mato Grosso Beekeepers Cooperative (COAPISMAT), located in the municipality of Conquista D'Oeste, region VII (Southwest) that provide 2,021 kg, to 951,059 kg of produce from the Poconé Rural Producers' Mixed Cooperative (COMPRUP), based in Poconé, region VI (South) (Figure 3). 

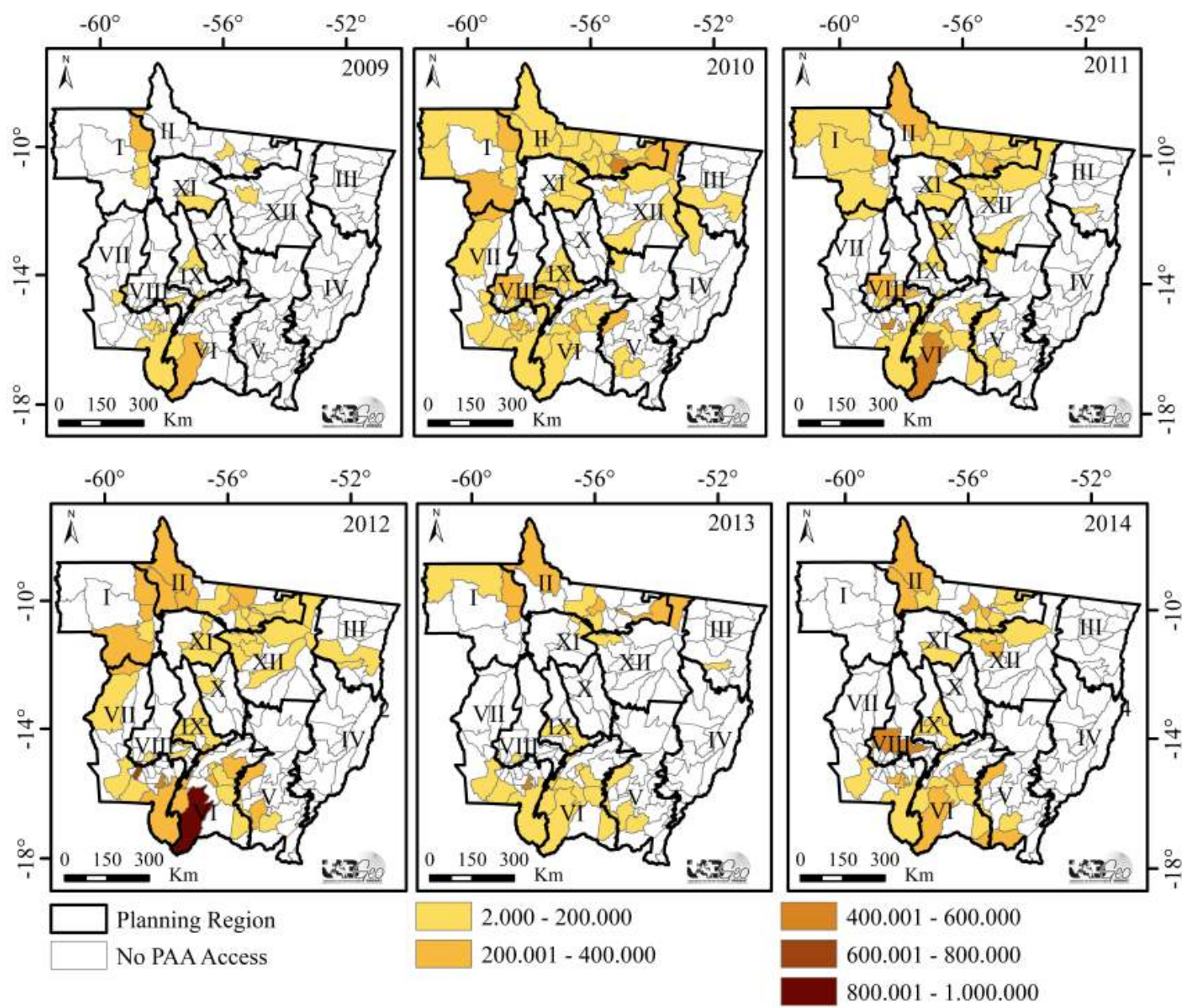

Figure 3 - The quantity of food (kg) from peasant agriculture traded via PAA-CDS by municipality and planning region in Mato Grosso from 2009 to 2014.

\section{Prepared by: LabGeo/UNEMAT.}

In $2009,1,627,112 \mathrm{~kg}$ of food from peasant agriculture were sold via the program, distributed in eight planning regions of Mato Grosso. In 2010, the commercialized products totaled 5,979,241.16 kg located in 11 planning regions. In 2011, this figure was 6,178,466 kg in 11 planning regions. In 2012, sales reached their highest level, with $8,847,690 \mathrm{~kg}$ of food traded in 11 planning regions. In 2013, $3,351,139 \mathrm{~kg}$ were sold in nine planning regions. In 2014, 5,324,029 $\mathrm{kg}$ were sold in eight state planning regions. However, the government and the global food industries try to convince us that they are responsible for food production (PIMBERT, 2009).

From 2009 to $2014,31,307,677 \mathrm{~kg}$ of peasant products were traded, indicating that despite all the difficulties and the prevailing agribusiness-based development model, peasant farmers produce and contribute to food production and food sovereignty. Peasant agriculture is responsible for about $70 \%$ of the food consumed and is decisive in the supply chain for the domestic market: cassava $(87 \%)$, beans (70\%), pork (59\%), milk (58\%), poultry and eggs (50\%) and maize (46\%) (MDA, 2015).

The foods on offer are of good quality and extremely varied, a total of 123 products are supplied to the PAA-CDS, which can be divided into 11 categories: 1) Agroindustrial (brown sugar, cookies, crackers, cake, corn hominy, milk drinks, babassu flour, banana flour, manioc flour, cornflour, manioc starch, pasta, molasses, treacle, vegetable oil, corn paste, bread, açai pulp, araçá pulp, buriti pulp, fruit pulp, pitanga pulp, tamarind pulp, tangerine pulp, cupuaçu pulp, araçá-boi pulp, fermented cassava flour, cheese, ground peanut, unrefined cane sugar, curd, donuts and pies); 2) Meat and animal products (beef, chicken, fish, lamb, pork, honey, and chicken eggs); 3) Chestnuts (babassu, cumbaru, and Brazil); 4) Cereals (processed rice, coffee, and maize); 5) Condiments (coloring, seasoning, and annatto); 6) Sweets 
(milk, pumpkin, banana, coconut, guava, and papaya); 7) Fruits (avocado, pineapple, acerola cherry, pumpkin, zucchini, banana, eggplant, cashew, star fruit, edible calabash, chayote, coconut, babassu coconut, fig, sugar apple, guava, soursop, jackfruit, jatoba, African eggplant, orange, lemon, papaya, mango, pumpkin, murici, souari nut, pepper, bell pepper, pinha, okra, tomato, and grape); 8) Grasses and palm hearts (sugar cane, palm heart, and pupunha); 9) Vegetables (watercress, chard, lettuce, wild chicory, broccoli, onion, chives, spring onion, chicory, coriander, kale, cauliflower, spinach, gherkin, mustard, cabbage, parsley, and mint); 10) Legumes (peanuts, peas, beans, and runner beans); 11) Tubers (saffron, potato, sweet potato, beet, oca, carrot, yam, radish, cassava root, and malanga).

The production can be broken down as follows: fruits $23 \%$, vegetables $21 \%$, processed foods $13 \%$, cereals $11 \%$, tubers $10 \%$; meat and animal products $9 \%$, legumes $7 \%$, sweets $3 \%$, nuts $1.5 \%$, grasses and palm hearts $1 \%$, and condiments $1 \%$. Camargo et al. (2013) highlighted the vegetable and tuber crops in the municipality of Itapetininga/SP, especially lettuce, chicory, pumpkin, and cassava. Deves and Rambo (2013) registered the predominance of wheat, rice, beans, cassava and maize in São Pedro do Butiá/RS. Both of these examples involved PAA projects.

All of the foods mentioned above offer a varied, high-quality diet for the PAA-CDS recipients and the peasant producers, who only trade their surplus crops; an added bonus is that many peasants do not use pesticides. In this sense, public policies such as the PAA prioritize respect for healthy eating habits, value local and regionalized foods, and also favor each region/municipality's agricultural vocation, thus fostering the development of the local economy (FBSSAN, 2009).

Ploeg (2009) states that in recent years the peasants have achieved some socio-political and economic space, and have participated in several state bodies, through the implementation of public policies such as the PAA and the creation of forums for debate, such as the National Food Security Council (CONSEA). This author warns that "[...] if these spaces are more and more limited, drastic setbacks may occur. This means that those who promote the peasantry must contribute to the expansion of autonomy, strengthening production and sustainability" (PLOEG, 2009, p. 30).

Furthermore, the foods produced in Mato Grosso and marketed by means of the PAA-CDS are highly acceptable to the recipients. According to the Caceres Municipal School Food Coordination (CAE/Cáceres City Hall/MT) in 2014, the acceptance level of peasant agriculture products served in meals in the municipal schools was $90 \%$.

Another example is the municipality of Mirassol D'Oeste, where the approval rate reached $87 \%$ at the Zumbi dos Palmares Municipal School, located in the Margarida Alves settlement, according to the school heads. In the municipality of Poconé, a survey by COMPRUP showed the level of endorsement by the receiving entities at $91 \%$, thus highlighting the peasants' contribution to the promotion of food sovereignty.

Food sovereignty fosters the community's autonomy by allowing peasant farmers to decide which seeds to plant, which animals to raise, what type of agriculture to practice, and which economic exchanges to participate in [...]. Food sovereignty points to the people's and the government's responsibility for considering the local consequences of political and economic processes at the macro-level (PIMBERT, 2009, p. 43).

Another notable point regarding the promotion of food sovereignty is that the PAA-CDS has helped create food distribution networks in several municipalities in Mato Grosso. The foodstuffs are distributed through the recipient bodies, reinforcing the menu served in various non-profit institutions. Throughout the state there are numerous social entities that receive food through the program, including schools, kindergartens, hospitals, nursing homes, churches, pastoral groups and other not-for-profit institutions (Figure 4). 

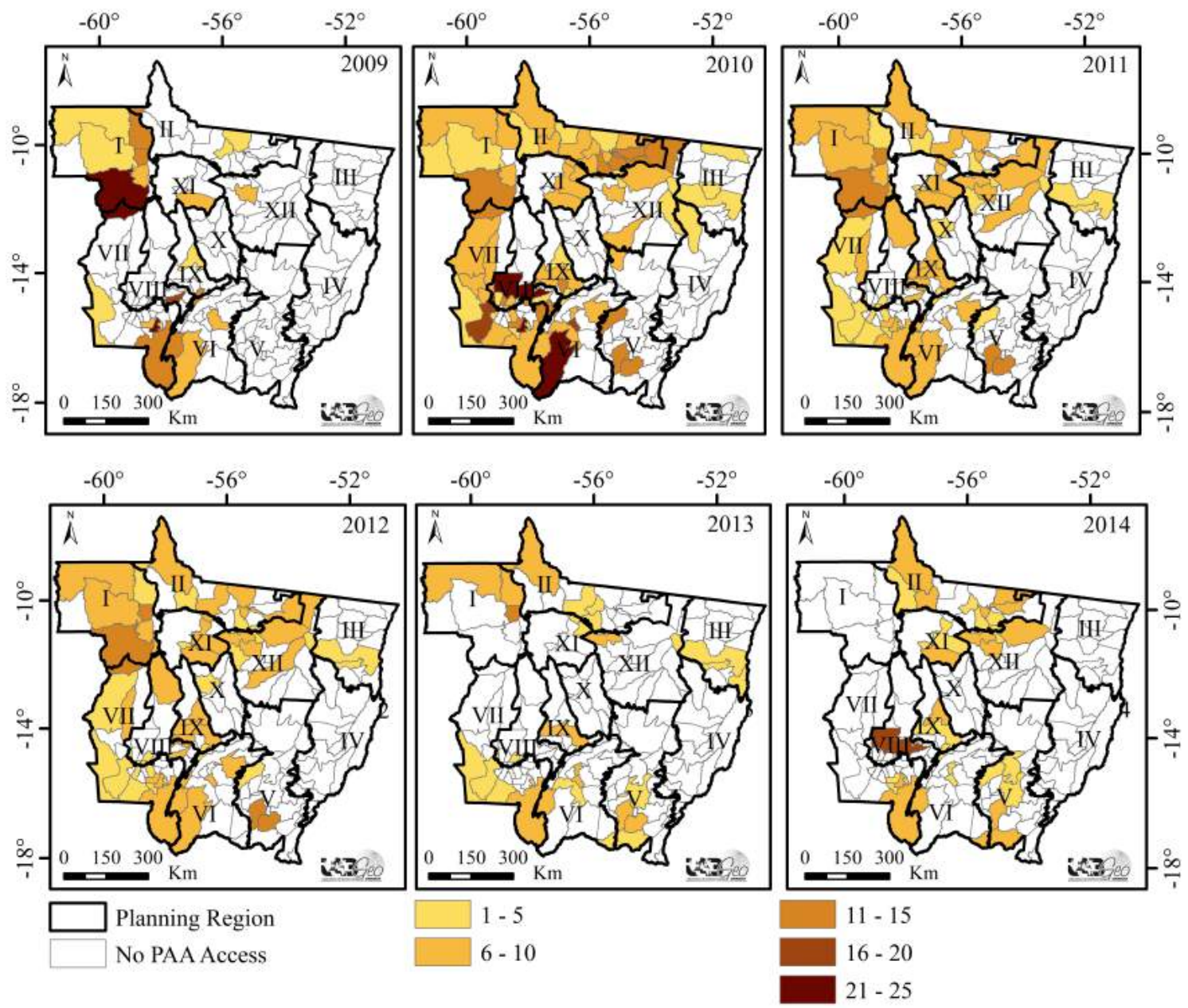

Figure 4 - The number of entities receiving food from peasant agriculture, via PAA-CDS, by municipalities and planning regions of Mato Grosso, from 2009 to 2014.

Prepared by: LabGeo/UNEMAT.

In 2009, 180 recipient entities benefited from the program, they were distributed in eight planning regions in Mato Grosso; region I (Northwest I) had the largest number, 63 entities in total. In 2010, this figure had risen to 521 entities located in 11 planning regions, region VII (Southwest), had the most organizations, 143 in total, making it the second-largest applicant for PAA-CDS projects in Mato Grosso in the six years analyzed.

In 2011, there were 418 entities in 11 regions, with region II (North) having the highest number of PAA-CDS food recipients, 89 in total. In 2012, there were 342 entities in 10 planning regions, with region I (Northwest I) having the largest number of organizations, 60 in total.

In 2013, there were 124 recipient groups in nine planning regions, region I (Northwest I) had 26 entities in total. In 2014, there were 165 bodies in eight planning regions in Mato Grosso, region II (North) led with 49 entities.

Between 2011 and 2014, regions I (Northwest), VII (Southwest) and II (North) had the highest number of recipients of peasant agriculture products, this is because the Southwest and North put forward the most PAA-CDS proposals. The North supplies its own region and the neighboring Northwest I region. The receiving groups play a strategic role in strengthening institutional markets, as well as certifying the products delivered for subsequent payment from Conab (MENDES, 2017).

In Mato Grosso 1,750 social entities have benefitted from PAA-CDS projects, demonstrating that it is possible to invest in short food production and consumption circuits that are compatible with the peasants' productive chains (MALUF, 2004). These short circuits offer greater autonomy to peasants and consumers, besides respecting local culture and traditions, agroecological production and food 
sovereignty (DAROLT; LAMINE; BRANDEMBURG, 2013).

Public policies can also be directed towards the creation of permanent information campaigns that emphasize the intrinsic qualities of ecological food, ethical values and the productive processes involved, as well as the positive impacts of their production on the environment and the health of consumers, which can help influence consumer attitudes and perceptions. Brazilian experiences show that alternative short marketing circuit systems can contribute to the adoption of healthier consumption habits and a better understanding of the difficulties of agricultural production (DAROLT; LAMINE; BRANDEMBURG, 2013, p. 12).

Due to the dynamic nature of the PAA-CDS, it is possible for peasant organizations to directly supply consumers (recipient entities) without the figure of the intermediary, with autonomous production and the sustainable use of natural resources. The peasants have greatly contributed to coining the concept of food sovereignty, conquering new unreached spaces such as institutional markets through government procurement (PIMBERT, 2009).

Additionally, the PAA-CDS does not just supply social entities; municipal social action secretariats may approach the regional Conab or a peasant organization directly, to include families at risk of food insecurity. These families receive food directly from the peasant farmers, on specified days and places, for a period of time.

This study also analyzed how many people benefited directly from the PAA-CDS policy in Mato Grosso. This number refers to the total number of people assisted by the recipient entities (schools, kindergartens, hospitals, nursing homes, churches, and pastoral groups) who received food from peasant agriculture.

In 2009, 62,032 people were served directly through the PAA-CDS modality. In 2010, the total reached 305,458 people and fell to 269,815 in 2011. In 2012, 204,087 people were assisted. In 2013, the number of people dropped to 145,397 people and in 2014, the number was 167,997 (Figure 5). 

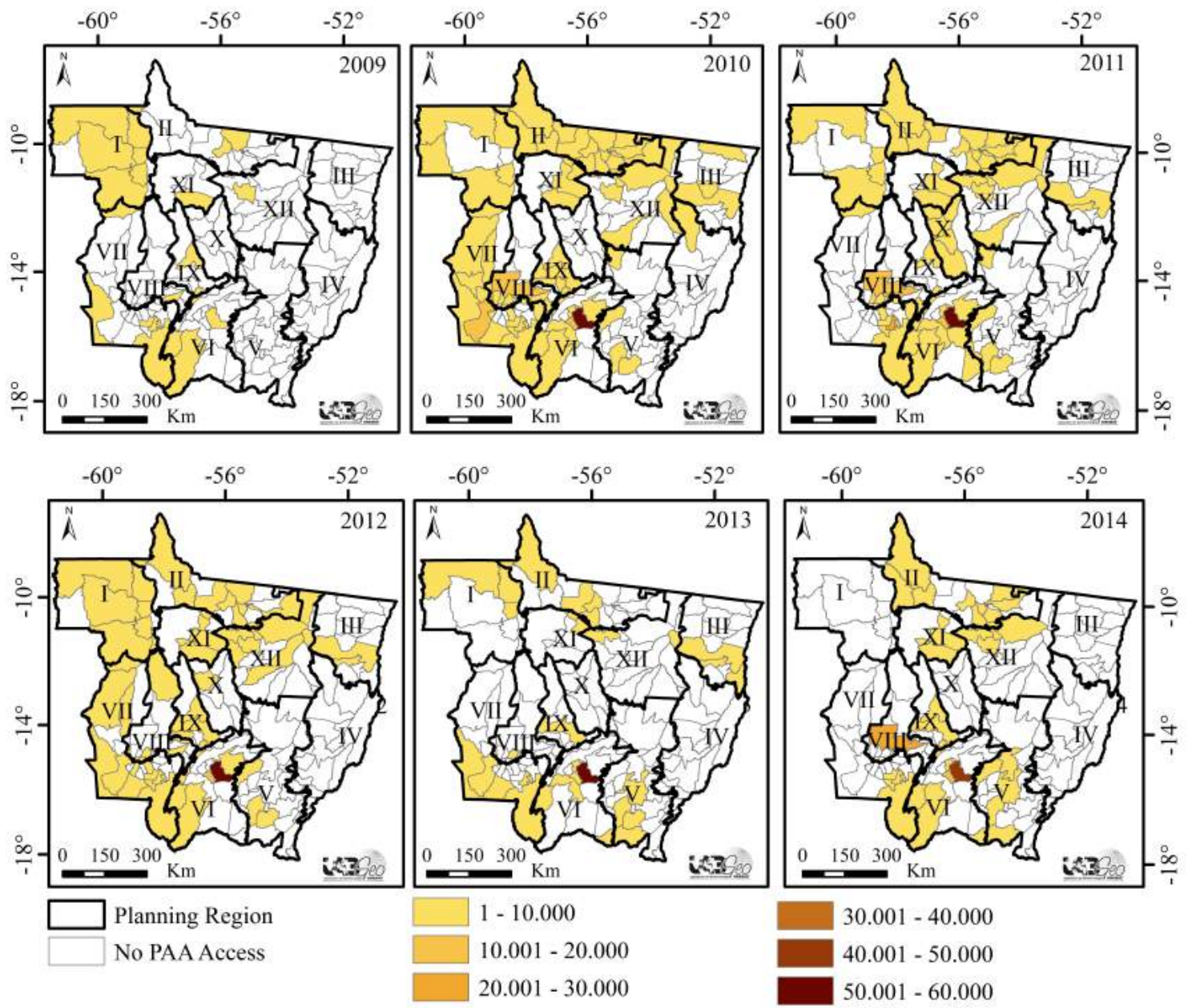

Figure 5 - The number of beneficiaries of food from peasant agriculture, via PAA-CDS, by municipality and planning region in Mato Grosso, from 2009 to 2014.

Prepared by: LabGeo/UNEMAT.

During the six years of the PAA-CDS [2009-2014] in the various regions of Mato Grosso $1,154,786$ people in rural and urban areas benefited directly from good-quality food. In this sense, the PAA-CDS contributes to the task of implementing food sovereignty beyond the rural population, by including the most underserved urban populations (MALUF, 2004).

In 2009, in the municipality of Mirassol D'Oeste alone, there were 6,592 individuals who benefited, which was the highest cover in the entire state for this year, by municipality. In 2010, 2011, 2012, 2013 and 2014 the municipality with the most people served was the capital Cuiabá, with 56,442, $57,318,58,376,55,543$ and 46,206 people served directly by the PAA-CDS, respectively. According to Pimbert, "peasant economies respect values because they know how to combine production for self-consumption and for the market", (2009, p. 44).

In short, the PAA is an important and strategic policy for peasant agriculture, strengthening diversified production, household consumption and food sovereignty both among the peasants and the people who are served by the program. Pimbert's studies (2009) indicate that "food sovereignty implies greater citizen participation and more direct forms of democracy in the management of food systems" (PIMBERT, 2009, p. 45).

\section{CONCLUSIONS}

In the context of Mato Grosso, the PAA is insufficient to meet all the demand in the State, since in many planning regions there is not a single PAA project. However, in 2016, it was observed that numerous community-based organizations were no longer served by the program due to the Conab's lack of financial resources, showing that diversified production for domestic supply is not a priority for 
governments.

The PAA in Mato Grosso works on social inclusion, strengthening peasant agriculture, producing quality food in sufficient quantities to meet the consumption of the family itself, with the possibility of marketing the surplus. Thus, food sovereignty affirms the right of the peasants and people served by the program to culturally appropriate food and access to resources to produce food, thus reducing their dependence on global markets. It also guarantees the right to manage natural resources such as land, water, and traditional seeds, thus prioritizing the preservation of biodiversity.

The PAA helped strengthen the associations, cooperatives, formal groups and other collectives who were energized, and gained autonomy and political training, as well as experience in productive, administrative and financial management. The program also acts directly in the social organization and production of settlements and rural communities, as it encourages collective production via official organization. These advances are explicit in many community-based organizations and women's groups that collectively manage the program's financial resources, generating benefits for the entire community.

Finally, the PAA has the potential to develop fairer markets for Mato Grosso's peasants and shorter commercialization circuits, offering the possibility of more favorable income and prices. However, it is necessary to advance the struggle to consolidate this policy in the State, by guaranteeing financial resources in the Federal Government budget and inserting people at risk of food insecurity into the program.

\section{REFERENCES}

ASSIS, S. C. R.; PRIORE, S. E.; FRANCESCHINI, S. C. C. Impacto do programa de aquisição de alimentos na segurança alimentar e nutricional dos agricultores. Ciência \& Saúde Coletiva, Rio de Janeiro, v. 22, n. 2, p. 617-626, 2017.

BRASIL. Lei $n^{\circ} .10 .696$ de 2 de julho de 2003. Dispõe sobre a repactuação e o alongamento de dívidas oriundas de operações de crédito rural, e dá outras providências. Disponível em: http://www.planalto.gov.br/ccivil_03/leis/2003/L10.696.htm. Acesso em: set. 2017.

BRASIL. Decreto no 7.775 de 4 de julho de 2012. Regulamenta o art. 19 da Lei $n^{\circ} 10.696$, de 2 de julho de 2003, que institui o Programa de Aquisição de Alimentos, e o Capítulo III da Lei n 12.512 , de 14 de outubro de 2011. Disponível em: http://www2.camara.leg.br/legin/fed/decret/2012/decreto-7775-4-julho-2012-613520-normaatualizada-p e.html. Acesso em: set. 2017.

CAMARGO, E. A. O. M.; GOMES, R. R. S.; MEIRA, B. C.; BORSATTO, R. S. Programa de Aquisição de Alimentos (PAA) como instrumento de fortalecimento de assentamentos rurais: o caso do assentamento 23 de Maio, Itapetininga, Estado de São Paulo. Informações Econômicas, São Paulo, v. 43, n. 1, p. 18-28, 2013.

CONAB. Manual da Companhia Nacional de Abastecimento (CONAB/SUREG/MT). Evolução do PAA em Mato Grosso. Cuiabá, MT, 2015, 32p.

CONAB. Manual da Companhia Nacional de Abastecimento: a participação dos assentados no Programa de Aquisição de Alimentos. Brasília, DF, 2016. 78p.

CONCEIÇÃO, J. C. P. R. Política de comercialização agrícola no Brasil. In: GRISA, C.; SCHNEIDER, S. (Org.). Políticas públicas de desenvolvimento rural no Brasil. Porto Alegre: Editora: UFRGS, 2015. p. 129-149.

DAROLT, M. R; LAMINE, C.; BRANDEMBURG, A. A diversidade dos circuitos curtos de alimentos ecológicos: ensinamentos no caso brasileiro e francês. Revista Agriculturas, Rio de Janeiro, v. 10, n.2, p. 8-13, 2013.

DEVES, O. D.; RAMBO, A. G. Mercados institucionais e a comercialização de alimentos na agricultura familiar: o Programa de Aquisição de Alimentos no município de São Pedro do Butiá-RS-BRASIL. 
Revista de Desenvolvimento Regional, Blumenau, v. 18, n. 1, p. 147-66, 2013.

FBSSAN. Fórum Brasileiro de Soberania e Segurança alimentar e Nutricional A terceirização da comida. Revista Proposta. Rio de Janeiro, v. 1, n. 33, p. 57-61, 2009.

GERHARDT, T. E.; SILVEIRA, D. T. Métodos de pesquisa. Porto Alegre: Editora da UFRGS, 2009. 120 p.

IBGE. Instituto Brasileiro de Geografia e Estatística. Censo Demográfico 2010. Disponível em: https://cidades.ibge.gov.br/brasil/mt/panorama. Acesso em: 25 fev. 2019.

JALIL, L. Soberania alimentar, feminismo e ação política. Revista Agriculturas, Rio de Janeiro, v. 6, n. 4, p. 9-12, 2009.

MALUF, R S. Mercados agroalimentares e a agricultura familiar no Brasil: agregação de valor, cadeias integradas e circuitos regionais. Ensaios FEE, Porto Alegre, v. 25, n. 1, p. 299-322, 2004.

MATO GROSSO. Plano de Desenvolvimento do Estado de Mato Grosso - MT + 20. Cuiabá: Secretaria de Planejamento do Estado de Mato Grosso, Cuiabá: SEPLAN, 2012. 108p.

MDA. Ministério do Desenvolvimento Agrário - MDA. Agricultura familiar produz $70 \%$ dos alimentos consumidos por brasileiro. 2015.2 Disponível http://www.brasil.gov.br/economia-e-emprego/2015/07/agricultura-familiar-produz-70-dos-alimentos-co nsumidos-por-brasileiro. Acesso em set. 2016.

MENDES. M. F. Agricultura familiar extrativista de frutos do Cerrado na região Sudoeste Mato-grossense - Brasil: produção e manejo ecológico. 2012. 75 f. Dissertação (Mestrado em Ambiente e Sistemas de Produção Agrícola) - Universidade do Estado de Mato Grosso, Tangará da Serra/MT, 2012.

MENDES, M. F. Políticas públicas em assentamentos rurais: potencialidades e limitações do PAA e do PNAE em Mato Grosso. 2017. 234 f. Tese (Doutorado em Geografia) - Universidade Federal de Goiás, Goiânia/GO, 2017.

MIRANDA, M. Empaer vive 10 anos de sucateamento. 2013. Disponível em: $\mathrm{http} / /$ circuitomt.com.br/editorias/cidades/26335-empaer-vive-10-anos-de-sucateamento.html. Acesso em: set. 2016.

OLIVAL. A. A. Estudo Propositivo: Portal Território da Amazônia. Brasília: MDA, 2005. 156p.

PANDOLFO, M. C. O programa de Aquisição de Alimentos como instrumento revitalizador dos mercados regionais. Revista Agriculturas, Rio de Janeiro, v. 5, n. 2, p. 14-17, 2008.

PIMBERT, M. Mulheres e soberania alimentar. Revista Agriculturas, Rio de Janeiro, v. 6, n. 4, p. 41-46, 2009.

PLOEG, J. D. V. Sete teses sobre a agricultura camponesa. In: PETERSEN, PAULO (Org.). Agricultura familiar camponesa na construção do futuro. Rio de Janeiro: ASPTA, 2009. p. 17-33.

SAQUET, M. A. Abordagens e concepções sobre o território. $3^{\text {a }}$ ed. São Paulo: Outras Expressões, 2013. 193p.

SCHEUER, J. M.; NEVES, S. M. A. S.; MENDES, M. F. Produção agroecológica da agricultura familiar beneficiária do Programa de Aquisição de Alimentos no estado de Mato Grosso. Cadernos de Agroecologia, Porto Alegre, v. 9, n. 4, p. 1-10, 2014.

SCHIMITT, C. J.; GUIMARÃES, L. A. O mercado institucional como instrumento da agricultura familiar de base ecológica. Revista Agriculturas, Rio de Janeiro, v. 5, n. 2, p. 7-13, 2008. 